\title{
BEHAVIOR OF FOLLOWING HEALTH PROTOCOLS (KEEPING DISTANCE, WASHING HANDS AND WEARING MASKS) AS A FORM OF STATE DEFENSE IN THE ERA OF COVID-19
}

\author{
Hanna Wijaya ${ }^{1}$, Yohanes Firmansyah ${ }^{2}$ dan Slamet Tri Wahyudi ${ }^{3}$ \\ Faculty of Law, Pembangunan Nasional Veteran Jakarta University, Jakarta, Indonesia \\ hannawijaya@yahoo.com, yohanesfirmansyah28@gmail.com dan \\ slamettriwahyudi@upnvj.ac.id
}

Received : 26-02-2021

Revised : 22-03-2021

Accepted : 25-03-2021

\begin{abstract}
Introduction: COVID-19 has become one of the problems that attacks all elements of national and state life. The effects of the COVID-19 Pandemic are not only related to health, but also attack the social aspects and resilience of a country. It is not surprising that the COVID-19. Pandemic can be classified as a non-military threat to a nation. Purpose: This paper discusses the role of society through attitudes towards State defense such as Following Health Protocols (Keeping Distance, Washing Hands and Wearing Masks) as a Form of State Defense in the Era of COVID-19. Method: This research is a literature review study that discusses social issues using 3 types of approaches, namely the statute approach, conceptual approach and case approach. Results: The results of this study reveal that we need to adjust to new behaviors in order to be healthier, safer and more compliant. We need to use all tools available to motivate citizens. The role of the community in breaking the chain of transmission of the disease COVID-19 (risk of contracting and transmission) must be carried out by implementing a number of health protocols. Conclusion: The conclusion of this study is that COVID-19 has become a very big problem for all countries, forcing the security of the state. The main thing the community can do to combat a disease is with the Following Health Protocols such as Keeping Distance, Washing Hands and Wearing Masks.
\end{abstract}

Keywords: state defese; health protocols COVID-19;

keeping distance; washing hands; wearing masks.

\section{INTRODUCTION}

Defending the state is a positive action to raise awareness of state defense in every citizen who has the rights and obligations to defend his country. A sense of full responsibility and willingness to sacrifice for the nation and its state, as well as patriotism and nationalism, are fostered by state awareness programs. In implementing state responsibilities, all citizens can contribute in many ways. In the midst of a COVID-19 
pandemic, we must physically defend the state in order to maintain a separation between individuals and society in order to break the chain of COVID-19. A country will be regarded as large if it has the capacity to overcome adversity. According to Mahipal (2011), the state can create citizen awareness by highlighting the importance of rights and responsibilities. Awareness of national defense must be developed through motivation to love one's country and to participate in defending the state (Widodo, 2011).

Today, widespread across the world, including in our country, Indonesia is under threat, from the deadly virus Corona Virus Disease 2019 or COVID-2019. Violidicidin was first identified in Wuhan City in the final quarter of 2019. Later on, various countries adopted this mask. WHO has stated that COVID-19 can be transmitted from an infected person. This disease is easily transferred from the tongue and mucus membranes through saliva and sneezing. If a person touches, then they will become infected. The person will then touch their nose, eyes, mouth and will become infected. This disease is caused by the SARS Coronavirus 2 (SARS-CoV-2). This new coronavirus has been found in humans for the first time. Wuhan is located in southwestern Hubei province of China and is the capital of Hubei Province. At the beginning of December 2019 in the month of diagnosis, suffering from flu was not unusual. On December 31, 2019, the World Health Organization received confirmation from the Chinese government that the epidemic had reached its peak and was beginning to decline. The virus spread around, beginning in Wuhan, then being spread to many other cities and countries. At first, the COPY-19 disease was a global epidemic. Later, it became a pandemic. In every country, there was an increase in diagnoses.

The controversy sparked several countries to consider measures to prevent the spread of the disease. Efforts made by the local government and the efforts of the central government of each country. But, despite the increase in cases, incidence is still occurring in various places. Based on the goal of ensuring health for all, WHO has identified certain health protocols that the general public should follow. In Indonesia, the CDC first discovered COVID-19 in March of 2020. With the addition of faster-than-average cases, the score will rise. However, it is very difficult to determine the proper patient. Because every patient tested positive has had contact with a family member and coworkers, both at home and work. Everyone who has been in contact with the contaminated patient will be contacted by his or her coworkers and family members. To introduce the Indonesian government to the recommendation of the WHO which recommends using masks, hand washing with soap, carrying hand sanitizers, maintaining distance from others or what is often referred to as social distancing and independent isolation. Due to the newness of COVID-19, it has caused many new changes because there is still a lot of research being done to find out more about this disease. Consequently, today people are waking up to the importance of implementing the WHO standard in healthcare. Despite the fact that there are many people who have not been able to comply with existing regulations, the central and local governments have made various efforts to resist the spread of disease (Wu et al., 2020).

The purpose of this study is to discuss the role of society through attitudes towards State defense such as Following Health Protocols (Keeping Distance, Washing Hands and Wearing Masks) as a Form of State Defense in the Era of COVID-19.

\section{METHOD}

This research is based on literature review. The literature search took place from January 1, 2021 to January 31, 2021. The search for data was carried out on various search engines such as Google Scholar. 
The research method was in the form of a normative legal and sociology review that studied the application of values in positive law by analyzing regulations related to the "Behavior of Following Health Protocols (Keeping Distance, Washing Hands and Wearing Masks) as a Form of State Defense in the Era of COVID-19" using various approaches: statute approach, conceptual approach and case approach.

This study examines strategic issues from a juriditive normative point of view. Some of the data sources used in this study are credible secondary data sources. The secondary data sources in this study are divided into two, namely library sources and secondary sources of law. Library sources in this research include books, journals, and other written documents. Secondary legal materials used in this research consist of applicable laws, court decisions, legal theory, doctrine, and expert opinions presented in the form of written documents.

\section{RESULTS AND DISCUSSION}

\section{A. COVID 19}

Coronavirus 2019 (CV-2019) is a new type of coronavirus that causes an infectious disease. Wuhan is located in southwestern Hubei province of China and is the capital of Hubei Province. In December of last year, a person was diagnosed with pneumonia. The cause of the disease is not yet fully understood. On December 31, 2019, the Chinese government officially reported the outbreak of 41 cases of pneumonia and no cause has yet been determined (WHO). It quickly became clear that the cause was not clear, and the disease spread prevalently to other areas and other countries. Thailand was the first country to contract the new type of coronavirus which was an old coronavirus (2019-nCoV). On January 30, 2020 the World Health Organization (WHO) declared a world health emergency due to an outbreak of Corona Virus. The number of patients with this new coronavirus is increasing very fast. The name was later changed to COVID-19 and was announced by WHO on February 11, 2020. On March 2, 2020, Indonesia's government publicly confirmed two Indonesian's who tested positive for COVID-19, which is said to be the first confirmed case of the virus in the country. As a result of the epidemic development in all parts of the world, the COVID-19 pandemic was declared by the WHO on March 11, 2020 (Sohrabi et al., 2020).

Coronavirus Disease 2019 (COVID-19) is a new, previously unknown, type of disease that is currently affecting humans. The virus that causes the aforementioned acronym is called SARS-CoV-2. Corona viruses are considered zoonotic (transmitted between animals and humans). Due to the ongoing sources of transmission of COVID-19, the animal remains unknown. Based on scientific research, COVID-19 can be transmitted through droplets in coughs and sneezes. The people most likely to get this disease are those who care for patients such as those with COVID-19 (Gondouin, 2020; Kannan et al., 2020; Rothan \& Byrareddy, 2020; Tim COVID-19 IDAI, 2020).

While the spread of COVID-19 is an ongoing concern, it should be mitigated by implementing comprehensive health protocols. Exposure to pesticides without protective gear has also become a serious problem in Indonesia. In addition to the fact that there are fewer personal protective equipment, there are few masks and no containment facilities in hospitals in the era of the COVID-19 pandemic. Initially in Indonesia, people panicked because of this news related to COVID-19, which made people buy masks and hand sanitizers in large quantities which is also referred to as "panic buying" which causes the supply of these products to be so scarce that they 
don't even exist in market. Even though these items are on the market, they are more expensive than the other competitive goods (Suni, 2020).

Symptoms felt by one person will vary in another's presence. For mild to severe symptoms, there are people who don't experience any and for people who do not experience any symptoms, the person will still feel healthy. Most people experience symptoms such as high fever, dry cough and fatigue. Sometimes the patient feels pain, nasal congestion, headache, runny nose, inflammation of the conjunctiva and sore throat, along with feeling nauseous and a red rash on the skin. Current cases that have occurred and the symptoms and severity of the cases. Certain medical conditions often worsen at the same time as the patient. (Amalia et al., 2020).

To diagnose COVID-19, WHO recommends conducting a PCR examination or what we usually call a swab examination. But because the PCR examination takes a long time, initially a quick examination is carried out or what is called a rapid test. However, there are still many places that cannot reach the community for inspection, this is because the tools and materials for inspection are still very limited, although over time more and more tools and materials have been found but the examination is still small (Burhan et al., 2015).

Current research in the treatment of COVID-19 is still on going to determine the right therapy for patients. There is currently no vaccine or specific drug that provides a protective benefit to prevent and treat this COVID-19 disease. Treatment that can be done at this time covers those aspects which correspond to the various symptoms appearing (Tim COVID-19 Indonesia, 2020).

\section{B. THREATS IN THE SOCIAL-CULTURAL FIELD}

With globalization penetrating diverse aspects of people's lives it is also increasingly threatening national defense in safeguarding state sovereignty, territorial integrity and national safety. To deal with multi-dimensional threats as stated above, handling not only rests on defense capabilities with a military dimension, but also involves defense capabilities with a non-military dimension as the embodiment of the State's universal defense system (Surahman, 2013; Yoga Agustin, 2011).

Based on the nature of the threat, this is categorized as an internal threat or an external threat. Non-military threats are essentially those brought about by threats against the sovereignty of the state, the territorial integrity of the country and the safety of the entire nation. No matter the dimension (ideology, politics, economy, culture, technology, information), both military and non-military threats can be identified. (Kemenhan, 2016; Mahendra Wiswayana et al., 2020; Timbul, 2016; Yulianti, 2018).

A threat with a socio-cultural dimension can be identified based on the internal and external nature of the threat. Threats from within are often the result of social justice concerns, poverty and backwardness. In this issue, problems such as "secession", "terrorism", "rampant violence" and "disasters caused by human actions" arise. These have become "germs" which threaten national unity, nationalism, patriotism and the integrity of the nation. An inherent and entrenched character of violence develops, such as a fire in the husks of the community which triggers inter-community conflicts or vertical conflicts between the central and regional governments. Horizontal conflicts with dimensions of ethnicity, religion, race and intergroup occur because of inherent nature of violence. Violence is an essential part of crime, which sometimes leads to environmental destruction, and sometimes to man-made disasters. These factors have become widespread, but will have an adverse effect on the Indonesian nation as a whole (Kemenhan, 2016; Mahendra Wiswayana et al., 2020; Timbul, 2016; Yulianti, 2018). 


\section{DEFINITION OF STATE DEFENSE (ATTITUDE)}

Awareness of your rights and obligations as a citizen of Indonesia is essential, and must be owned by every Indonesian citizen as a defense of their rights and obligations. The awareness of defending the country is the country's strongest asset and the basic foundation for the security and survival of the Indonesian nation and state. What a state defense law is according to Article 9 of Law number 3 of 2002 Paragraph (2) letter $\mathrm{b}$ which reads "what is meant by service in accordance with the profession is service to the state which has a certain profession for the interest of national defense, including in overcoming it and/ or minimizing the consequences caused by war, natural disasters, or others" (Indonesia, 2002).

In the form of defending our country as Indonesian citizens, what we can do in the midst of the COVID-19 pandemic or the corona virus which has disrupted and threatens the lives of the Indonesian people is by complying with policies issued by the central and regional governments, namely to keep people at a distance, to increase interpersonal distance, meticulously wash your hands, eat healthy foods and refrain from going out. Whereas Article 9 of Law number 3 of 2002 states that every citizen has the right and obligation to actively participate in efforts to defend the state. The manifestation of the will to defend the State is the readiness and willingness of every citizen to sacrifice themselves for the sake of upholding the integrity of the Indonesian nation, the unity of the archipelago, and the survival and national jurisdiction of the 1945 Constitution (Indonesia, 2002).

\section{RUNNING HEALTH PROTOCOLS AS A STATE FORM IN THE ERA OF COVID-19}

The community has an important role in breaking the chain of transmission of COVID-19 so as not to cause new sources of transmission/ clusters in places where the movement of people, interaction between humans and large gatherings of people occurs. The community must adapt to different habits in order to be healthier, cleaner and more obedient, which are carried out by all components of the community and by empowering all resources available. The role of the community in breaking the chain of transmission of the disease COVID-19 (risk of contracting and transmitting) must be carried out by implementing a number of health protocols such as: (Aftab, 2020; Gondouin, 2020; Kemenkes RI, 2020; Tim COVID-19 IDAI, 2020).

1. Use personal protective equipment in the form of a mask that covers the nose and mouth to the chin, if you have to leave the house or interact with other people whose health status is unknown (who might transmit COVID-19). If using a cloth mask, you should use a 3-layer cloth mask.

2. Clean your hands regularly by washing your hands with soap under running water or using an alcohol-based hand sanitizer. Always avoid touching your eyes, nose and mouth with unclean hands (which may be contaminated with droplets containing the virus).

3. Maintain a minimum distance of 1 meter from other people to avoid getting droplets from people who are talking, coughing or sneezing and avoiding crowds, crowds and overcrowding. If it is not possible to maintain a distance, various administrative and technical engineering can be carried out. Administrative engineering can be in the form of limiting the number of people, setting schedules, and so on. While technical engineering, among others, can be in the form of partitioning, setting entry and exit routes and so on.

The importance of implementing health protocols is the strongest because it will further help the government reduce the current rate of the COVID-19 virus. The 
need for public awareness from not causing a crowd to gather in a place. In everyday life, it has become a very effective way, in the workplace and in the household environment. (Aftab, 2020; Kemenkes RI, 2020; Sohrabi et al., 2020; Wang et al., 2020).

\section{E. STATE DEFENSE IN HANDLING COVID-19}

A country will be regarded as large if it has the capacity to overcome adversity. Efforts are made to defend the state, expecting every citizen to understand their rights and expectations. Through providing a motivating process, people need to be encouraged to love the country and participate in defending the state. The worldwide Corona Virus is frightening many people. First, among the factors supporting the existence of social distancing is that it is a form of state defense against the Indonesian State. By limiting all activities outside the home can save the state of Indonesia, by obeying the community to continue at home as long as there is this Corona Virus, the community breaks the chain of this Corona Virus so as not to contract or transmit it to other humans. Second, express appropriate emotions. Our modern social media are indeed free spaces for everyone to express personal feelings. However, my disorder is not the only cause of my difficulties.

Moreover, some people also have very sensitive skin. When a person has a sneezing and coughing condition. It is normal to not shake hands and say "cipika cipiki" these days. Third, build solidarity with other members of the audience. When there is a part of society affected by the virus, what is needed is a level of empathy with those who are suffering and threatened. No one wants to be single. When someone has a cough, fever and indications of flu, then with full self-awareness to comply with health protocols, for example wearing a mask, stay away from the crowd and others. It was important to have the courage to continue to pray for peace as the COVID-19 pandemic case continues. These four actions are part of laying the groundwork for how we will respond to the future threat posed by the COVID-19 crisis. Defending the state is not always through heroic action such as during the fight for independence, but people of good will work together to achieve common goals. If you are unable to control or reasonably limit yourself, you should not be allowed to harm others (Hs, 2020; Mareta, 2020; Nurhalimah, 2020b, 2020a; Oktami Putri, 2020; Shabrina, 2020).

\section{CONCLUSION}

COVID-19 has become a very big problem for all countries to the point of threatening the security of the State. One form of State defense and an attitude of nationalism that the community can take to overcome COVID-19 and help the State is by doing simple things, such as following health protocols (keeping distance, washing hands and wearing masks) as a form of state defense in the era of COVID-19.

\section{BIBLIOGRAPHY}

Aftab, R. (2020). Coronavirus (COVID-19). InnovAiT: Education and Inspiration for General Practice. https://doi.org/10.1177/1755738020938394 
Amalia, L., Irwan, I., \& Hiola, F. (2020). Analisis Gejala Klinis Dan Peningkatan Kekebalan Tubuh Untuk Mencegah Penyakit COVID-19. Jambura Journal of Health Sciences and Research. https://doi.org/10.35971/jjhsr.v2i2.6134

Burhan, E., Isbaniah, F., Susanto, A. D., Yoga, T., Aditama, Soedarsono, Sartono, T. R., Sugiri, Y. J., Tantular, R., Sinaga, B. Y., Handayani, R. . D., \& Agustin, H. (2015). PNEUMONIA COVID-19 DIAGNOSIS \& PENATALAKSANAAN DI INDONESIA. In Journal of the American Pharmacists Association. https://doi.org/10.1331/JAPhA.2015.14093

Gondouin, B. (2020). COVID-19. Nephrologie et Therapeutique. https://doi.org/10.1016/S1769-7255(20)30419-3

Hs, H. (2020). Mengenal Makna Bela Negara di Masa Pandemi Virus Corona (Know the Meaning of Defending the Country in the Corona Virus Pandemic Period). SSRN Electronic Journal. https://doi.org/10.2139/ssrn.3575683

Indonesia, U. R. (2002). Undang-Undang Republik Indonesia Nomor 3 Tahun 2002 Tentang Pertahanan Negara. Peraturan Pemerintah Republik Indonesia Nomor 3 Tahun 2002.

Kannan, S., Shaik Syed Ali, P., Sheeza, A., \& Hemalatha, K. (2020). COVID-19 (Novel Coronavirus 2019) - recent trends. European Review for Medical and Pharmacological Sciences. https://doi.org/10.26355/eurrev_202002_20378

Kemenhan. (2016). Bela Negara Dan Kebijakan Pertahanan. Majalah WIRA.

Kemenkes RI. (2020). Pedoman Pencegahan dan Pengendalian Coronavirus Disease (COVID-19). Germas.

Mahendra Wiswayana, W., Komang, N. I., \& Arya Pinatih, D. (2020). Pandemi dan tantangan ketahanan nasional indonesia: sebuah tinjauan kritis. Jurnal Kajian Lemhannas RI.

Mareta, V. A. (2020). Aktualisasi Bela Negara dalam menghadapi pandemi COVID-19 (Actualization of Defending the Country in the Face of the COVID-19 Pandemic). SSRN Electronic Journal. https://doi.org/10.2139/ssrn.3575467

Nurhalimah, N. (2020a). Upaya Bela Negara Melalui Sosial Distancing Dan Lockdown Untuk Mengatasi Wabah Covid-19. SSRN.

Nurhalimah, N. (2020b). Upaya Bela Negara Melalui Sosial Distancing Dan Lockdown Untuk Mengatasi Wabah COVID-19 (Efforts to Defend the Country Through Social Distancing and Lockdown to Overcome the COVID-19 plague). SSRN Electronic Journal. https://doi.org/10.2139/ssrn.3576405

Oktami Putri, A. (2020). Aktualisasi Nyata Bela Negara Saat Pandemi COVID-19 (Real Actualization of the State Defense When the COVID-19 Pandemy). SSRN Electronic Journal. https://doi.org/10.2139/ssrn.3580876 
Rothan, H. A., \& Byrareddy, S. N. (2020). The epidemiology and pathogenesis of coronavirus disease (COVID-19) outbreak. In Journal of Autoimmunity. https://doi.org/10.1016/j.jaut.2020.102433

Shabrina, S. (2020). Memperkuat Kesadaran Bela Negara Di Tengah Pandemi COVID-19 (Strengthening the Awareness to Defend the Country in the Middle of the COVID-19). SSRN Electronic Journal. https://doi.org/10.2139/ssrn.3576300

Sohrabi, C., Alsafi, Z., O’Neill, N., Khan, M., Kerwan, A., Al-Jabir, A., Iosifidis, C., \& Agha, R. (2020). World Health Organization declares global emergency: A review of the 2019 novel coronavirus (COVID-19). In International Journal of Surgery. https://doi.org/10.1016/j.jisu.2020.02.034

Suni, N. S. P. (2020). Kesiapsiagaan Indonesia Menghadapi Potensi Penyebaran Corona. Pusat Penelitian Badan Keahlian DPR RI.

Surahman, S. (2013). Dampak Globalisasi Media Terhadap Seni dan Budaya Indonesia. Jurnal Komunikasi.

Tim COVID-19 IDAI. (2020). Protokol Tatalaksana Covid-19. 1.

Tim COVID-19 Indonesia. (2020). Protokol Tatalaksana Covid-19. 1.

Timbul, S. (2016). Bela Negara Dan Kebijakan Pertahanan. Majalah WIRA.

Wang, C., Pan, R., Wan, X., Tan, Y., Xu, L., Ho, C. S., \& Ho, R. C. (2020). Immediate psychological responses and associated factors during the initial stage of the 2019 coronavirus disease (COVID-19) epidemic among the general population in China. International Journal of Environmental Research and Public Health. https://doi.org/10.3390/ijerph17051729

Yoga Agustin, D. S. (2011). Penurunan Rasa Cinta Budaya Dan Nasionalisme Generasi Muda Akibat Globalisasi. Jurnal Sosial Humaniora. https://doi.org/10.12962/j24433527.v4i2.632

Yulianti, D. (2018). Perang Global Melawan Terorisme dalam Perspektif Sekuritisasi. Jurnal ICMES. https://doi.org/10.35748/jurnalicmes.v1i2.13 